\title{
Otfrid Foerster, pionier en leermeester
}

Harvey Cushing is de bekendste pionier op het gebied van de neurochirurgie en Victor Horsley op het gebied van epilepsiechirurgie. In Duitsland werden aan het eind van de negentiende en het begin van de twintigste eeuw neurochirurgische ingrepen bij mensen met epilepsie gedaan door Fedor Krause en Otfrid Foerster. Vooral Foerster heeft als leermeester van Penfield veel betekend voor de epilepsiechirurgie.

De Amerikaan Harvey Cushing (I869I939) was een gigant op het gebied van de neurochirurgie. Zijn technische vaardigheden zorgden er voor dat veel patiënten een ingreep overleefden en een goed herstel lieten zien. De Engelsman Victor Horsley (I857-I9I6) was een van de eersten die met succes operaties uitvoerde bij mensen met epilepsie. Aan het eind van de negentiende eeuw speelde Duitsland een belangrijke rol op het gebied van de neurologie en neuropsychiatrie en werd gestart met neurochirurgische ingrepen voor epilepsie. Fedor Krause (1857-I937) begon hiermee in Berlijn en hij zou meer dan 400 mensen met epilepsie opereren. Zijn iets jongere collega Otfrid Foerster (I873-I94I) werkte in het toenmalige Breslau, het huidige Wroclaw in het zuidwesten van Polen. Hij had grote invloed op een jonge generatie neurochirurgen die later naam maakten in de epilepsiechirurgie.

\section{Otfrid Foerster}

Foerster studeerde geneeskunde in Freiburg, Kiel en Breslau waar hij een leerling was van Wernicke met wie hij een hersenatlas publiceerde (Tan \& Black, 200I). Wernicke schreef over Foerster 'dat hij nu een leerling had die de lamme kon laten lopen en de blinde kon laten zien'. Foerster studeerde op advies van Wernicke twee jaar in Parijs bij Joseph Babinski, Jules Dejerine en Pierre Marie. In I903, teruggekeerd naar Breslau, stierf zijn eerste dochter en dat veranderde hem in een introverte, op zijn werk geconcentreerde man. In IgII werd hij in het WenzelHancke Krankenhaus in Breslau benoemd tot de eerste hoogleraar neurologie (zonder psychiatrie) in Duitsland. Hij sprak vele talen waaronder Pools en Russisch. In I920 was hij betrokken bij de behandeling van een hersenbloeding bij Lenin. Dat maakte hem in Duitsland onbemind en hij werd min of meer buitengesloten. In I930 nodigde Cushing hem uit om tijdelijk bij hem te komen werken. Cushing was onder de indruk van Foersters werkkracht. In 1934 werd aan het Wenzel-Hancke ziekenhuis voor Foerster een neurologische kliniek gebouwd, betaald door de Rockefeller Foundation. Tijdens het Tweede Internationale Neurologische congres in London in 1935 ontving Foerster de Hughlings Jackson Memorial Medal en hield hij de Jackson Lecture. Hij bleef in eigen land persona non grata en het leven en werken werd hem steeds moeilijker gemaakt. In 1937
Otfrid Foerster ca. 1930 (met toestemming van het Archiv der Deutsche Gesellschaft für Neurochirurgie).

hield de British Association of Neurological Surgeons haar jaarlijke bijeenkomst in Foersters instituut. Foerster overleed op I5 juni I94I in Breslau, een dag later gevolgd door zijn vrouw. Veel inwoners van Breslau bewezen hem de laatste eer. Zijn nalatenschap bestaat onder meer uit 300 publicaties met eigen illustraties.

Foersters werk

Foerster viel in zijn tijd onder meer op doordat hij als neuroloog de weg vond naar de neurochirurgie en grotendeels als autodidact het vak leerde. Hij was actief op diverse deelterreinen van de neurologie en neurochirurgie, zoals tabes dorsalis (een langzame degeneratie van vooral sensorische neuronen in het ruggemerg), bewegingsstoornissen, spasticiteit, extrapyramidale stoornissen, in kaart brengen van de dermatomen, hersentumoren en pijn. Hij experimenteerde onder andere met de neurochirurgische behandeling van pijn op spinaal niveau. Hij had zeer beperkte middelen tot zijn beschikking: hij heeft gewerkt 
met één operatielamp plus een lamp die door een assistent werd vastgehouden. Middelen om met clips bloedingen te stoppen bestonden nog niet. Maar zijn technische vaardigheden en zijn neurologische kennis maakten hem tot een succesvol neurochirurg. In WO I behandelde hij als hoofd van de afdeling neurologie van een militair hospitaal duizenden patiënten. Hij experimenteerde met patiënten met epilepsie waarbij hij middels een craniotomie onder lokale verdoving de hersenschors elektrisch stimuleerde. In de meeste gevallen ging het om soldaten uit WO I die aan epilepsie leden ten gevolge van een hoofdtrauma. Dit leidde tot het eerste elektrocorticogram. In Igro liet hij de voordelen zien van een radicale excisie van littekenweefsel in de cortex door weefsel weg te halen tot aan de ventrikels. Wolff (I99I) schrijft dat Foerster in vergelijking met Krause een grotere belangstelling had voor klinische verschijnselen en de waarde daarvan inzag voor de lokalisatie van een onderliggende bron voor epilepsie.

Foerster introduceerde ook de hyperventilatietest om een epileptische aanval uit te lokken. Al lang geleden was er een gelijkenis gezien tussen krampen bij tetanie, dat wil zeggen een verhoogde prikkelbaarheid van de spieren en zenuwen, en epilepsie. Bij tetanie was geconstateerd dat met een geforceerde ademhaling een aanval kon worden uitgelokt en Foerster wilde proberen om op een soortgelijke manier een aanval uit te lokken bij patiënten met epilepsie. Gedurende tien minuten moest een patiënt, gezeten op een stoel, in- en uitademen, waarbij hij vooral sterk moest uitademen. Bij de helft van de 45 patiënten met epilepsie trad een aanval op tijdens deze procedure.

\section{Leermeester}

Van over de hele wereld kwamen jonge artsen naar Foerster in Breslau om het vak van de grote meester te leren. Daaronder waren onder meer John Fulton, Percival Baily en Paul Bucy, die later allemaal grote faam verwierven. In I930 ging Wilder Penfield voor een studiereis naar Europa om zich te oriënteren teneinde een nieuwe neurologische afdeling aan de McGill universiteit in Montreal te kunnen beginnen. Penfield heeft een verslag van die studiereis gemakkt en zijn bezoek aan Breslau wordt het meest gedetailleerd besproken (zie ook: http://digital.library.mcgill. ca/penfieldfonds). Vooral de samenwerking van Foerster en Penfield, die zes maanden in Breslau zou blijven, was zeer vruchtbaar. In een uitgebreid artikel van meer dan 30 pagina's over epilepsiechirurgie verwijst Penfield naar publicaties van Foerster: één uit 1926 over de pathogenese van epileptische aanvallen (Foerster, I926) en een tweede artikel over het belang van de behandeling (verwijdering) van de littekenvorming bij traumatische epilepsie (Foerster \& Penfield, 1930). Daarin worden interventies beschreven op verschillende plaatsen van de cortex op basis van klini- sche observaties; het EEG was hiervoor toen nog niet beschikbaar. Zij vergelijken ook hun bevindingen met de cytoarchitectuur van de cortex van Oskar Vogt (I870-I959), die ook werkzaam was in Breslau en medebehandelaar van Lenin. Allerlei verschijnselen na corticale elektrische stimulatie staan in het artikel beschreven. Wat hierbij opvalt is dat de temporaalkwab nog grotendeels onontgonnen gebied is (Penfield, I936). Volgens Wolff kwam dat doordat men de temporaalkwab chirurgisch niet goed kon bereiken, maar vooral ook omdat men dacht dat sclerose van de Ammon's hoorn (Eling \& Renier, 2018) een gevolg was van epilepsie, niet een oorzaak. Die samenwerking van Penfield met Foerster leidde tot het 'kopiëren' van Foersters werkwijze in het Montreal Neurological Institute, waar Penfield leiding ging geven. Ook dit instituut werd met behulp van middelen van de Rockefeller Foundation opgericht. In I937 zou Penfield nogmaals Foerster bezoeken in Breslau.

Tot slot

In 1937 kreeg Foerster van de British Association of Neurological Surgeons de titel van 'Member Emeritus'. Hij werd in 1953 in Duitsland gerehabiliteerd: de Deutsche Gesellschaft für Neurochirurgie stelde de Otfrid Foerster prijs in. Percival Baily was de eerste die deze prijs in ontvangst mocht nemen. Het Neurologisch Instituut in Breslau werd omgedoopt tot het Otfrid Foerster Institut für Neurologie. De epilepsiekliniek in Bonn draagt ook zijn naam. De laatste jaren wordt in toenemende mate het belang gezien van Foersters invloed op de ontwikkeling van klinische symptomen en de neurochirurgische behandeling van epilepsie (Piotrowska \& Winkler, 2007).

\section{Referenties}

Foerster O (I926) Die Pathogenese des epileptischen Krampfanfallen. Deutsche Ztschr $f$ Nervenh 94:15.

Foerster O, Penfield W (I930) The structural basis of traumatic epilepsy and results of radical operation. Brain 53:99-119.

Eling P, Renier W (2018) Hippocampus, Ammons hoorn en epilepsie. Epilepsie;1/16:19-21.

Penfield W (1936) Epilepsy and surgical therapy. Arch Neurol Psychiatry 36:449-484.

Piotrowska N, Winkler PA (2007) Otfrid Foerster, the great neurologist and neurosurgeon from Breslau (Wroclaw): his influence on early neurosurgeons and legacy to present-day neurosurgery. J Neurosurg 107:451-456. Tan TC, Black PM (200I) The contributions of Otfrid Foerster (I873-I94I) to neurology and neurosurgery. Neurosurgery. 49(5):1231-1235.

Wolff P (I99I) The history of surgical treatment of epilepsy in Europe. In: H. Lüders (ed) Epilepsy Surgery. New York, Raven Press. 